\title{
THE ORIGIN, CLASS AND SPECIFICITY OF IMMUNOGLOBULINS IN BOVINE CERVICO-VAGINAL MUCUS: VARIATION WITH PARENTERAL IMMUNIZATION AND LOCAL INFECTION WITH VIBRIO FETUS
}

\author{
B. N. WILKIE, * J. R. DUNCAN AND A. J. WINTER \\ New York State Veterinary College, Cornell University, Ithaca, N.X.
}

(Received 25 October 1971, accepted 18th January 1972)

\begin{abstract}
Summary. Cervico-vaginal mucus agglutinins occurred in heifers following either parenteral immunization with Vibrio fetus or transfer of serum from hyperimmunized cattle. Serum IgG was transported into the lumen of the reproductive tract. Thus, while serum agglutinins were of IgG and IgM classes, those in mucus were solely IgG. Agglutinins induced by immunization were predominantly of whole-cell specificity whereas those stimulated by local infection of the reproductive tract with $V$. fetus were directed toward the $\mathrm{O}$-determinant. The $\mathrm{O}$-agglutinins in vaginal mucus were of the IgA class and their synthesis within the reproductive tract appeared likely.
\end{abstract}

\section{INTRODUGTION}

Vibrio fetus venerealis infects female cattle at coitus and is restricted to the reproductive tract in which it stimulates at all levels inflammatory foci of lymphocytes and plasma cells (Vandeplassche, Florent, Bouters, Huysman, Brone \& DeKeyser, 1963). Infection is associated with infertility, apparently the result of early embryonic death (Adler, 1959). Specific agglutinins appear in cervicovaginal mucus of infected animals (Stegenga \& Terpstra, 1949; Terpstra \& Eisma, 1951; Florent, 1960) but serum agglutinating titres seldom increase significantly (Lawson \& McKinnon, 1952; Boyd, 1955; Winter, 1965; Larsen \& Ringer, 1967).

Convalescent resistance to infertility is marked (Hoerlein \& Carroll, 1970); however, reinfection or persistent infection is common without adverse effects on fertility (Vandeplassche et al., 1963; Frank, Bryner \& O'Berry, 1964). Immunization by subcutaneous injection with commercial oil emulsion or aluminium hydroxide-adsorbed bacterins results in increased fertility but, although infection is reduced in comparison with challenged non-vaccinates, a high percentage of fertile vaccinated animals do become infected (Hoerlein \& Carroll, 1970). Vaginal mucus agglutinins have not been detected following

* Present address: Vet.-Bakteriologisches und Parasitologisches Institut, Universität Bern, Bern Switzerland. 
systemic immunization (Clark, Newsam, Monsbough \& Dufty, 1967; Clark, Dufty \& Monsbough, 1968; Kramer \& Hoerlein, 1969) except by Clark, Dufty \& Monsbough (1970), who reported local agglutinins in animals which had been immunized with a strain of $V$. fetus intestinalis. Using a bacterin incorporating whole cells of either venereal or intestinal strains of $V$. fetus emulsified in Freund's complete adjuvant, we have successfully stimulated vaginal mucus titres in a number of heifers (Wilkie \& Winter, 1971b).

It is the purpose of this report to describe the origin, immunoglobulin class and specificity of antibodies occurring in vaginal mucus following either vaginal infection or parenteral immunization with $V$. fetus venerealis.

\section{MATERIALS AND METHODS}

\section{Animals and treatments}

The methods of infection and active immunization of heifers have been described elsewhere (Wilkie \& Winter, 1971b). Heifers were infected at oestrus by intracervical and intravaginal infusion of $1.8 \times 10^{5}$ viable $V$. fetus cells. Washed whole bacterial cells ( $V$. fetus venerealis), suspended in $0.3 \%$ formol saline to an optical density of 1.5 at $525 \mathrm{~nm}$, were emulsified with an equal volume Freund's complete adjuvant and injected subcutaneously into virgin heifers on two occasions 4 weeks apart. Each immunization consisted of $4 \mathrm{ml}$ adjuvant emulsion administered at four sites in the prescapular area. A single heifer was passively immunized by slow intravenous injection of 7 litres whole serum collected from three actively immunized heifers; no abnormal signs were observed at any time during or after this procedure. Serum and vaginal mucus were collected weekly before and after immunization or infection. Vaginal mucus was collected by tampon (Szabo, 1951) and extracted for use in the bacterial agglutination test with a quantity of formol-treated physiological saline proportional to its weight (Hughes, 1953). Samples contaminated by bleeding post oestrum were excluded from the study. Nasal secretions were collected and agglutinating activity determined as described by Duncan, Wilkie, Hiestand \& Winter (1972) and Duncan, Wilkie \& Winter (1972). For antigen in the agglutination test, either whole washed homologous $V$. fetus cells (whole cells) or similar cells which had been suspended for $2 \mathrm{hr}$ in a boiling water bath (boiled cells) were suspended in formol saline to an optical density of $0 \cdot 60$ at $525 \mathrm{~nm}$. Boiled $V$. fetus cells have been shown to lack a heatlabile somatic antigen and thus have exposed heat-stable $\mathrm{O}$ antigens (Wiidik \& Hlidar, 1955; Ristic, White, Doty, Herzberg \& Sanders, 1957). Antiserum prepared against boiled cells fails to agglutinate whole cells (Wiidik \& Hlidar, 1955; Ristic et al., 1957).

\section{Production of antisera}

The production of antisera monospecific for bovine IgG, IgM and IgA has been described (Duncan, Wilkie, Hiestand \& Winter, 1972). Anti-IgG was prepared in rabbits by injection of an emulsion of Freund's complete adjuvant containing serum pseudoglobulin eluted from diethylaminoethyl cellulose by 0.01 M-phosphate buffer, $\mathrm{pH} 8.0$. The antiserum was absorbed with bis- 
diazotized benzidine (BDB) insoluble bovine IgM. Anti-IgM was prepared in rabbits by injection in Freund's complete adjuvant of an immunoglobulin obtained from the serum euglobulin fraction by Sephadex G-200 gel filtration followed by starch block electrophoresis. The antiserum was absorbed with BDB insoluble bovine IgG. Anti-IgA was obtained from guinea-pigs immunized by the method of Binaghi, Oriol \& Boussac-Aron (1967). The immunizing material was prepared from bovine nasal washings by electrophoresis in Pevikon (Pevikon C-870, Mercer Chemical Co.) followed by gel filtration on Sephadex G-200. The resulting antiserum was absorbed with whole bovine serum rendered insoluble with $8.0 \%$ gluteraldehyde (Avrameas \& Ternynck, 1969). All three antisera were judged monospecific by their production of single precipitin arcs in immunoelectrophoresis against bovine serum or secretions and reactivity in a microsystem of agar gel diffusion (Munoz, 1971) with purified immunoglobulins only of the appropriate class.

\section{Fractionation of serum and cervico-vaginal mucus extracts}

Samples of serum and cervico-vaginal mucus extracts selected for high agglutinating titre were divided into three $0.5-\mathrm{ml}$ aliquots for centrifugation on $4 \mathrm{ml}$ of a continuous 10 to $40 \%$ sucrose gradient at $30,000 \mathrm{rev}$. $/ \mathrm{min}$ for $15.5 \mathrm{hr}$ in a Spinco model L centrifuge (Spinco Division, Beckman Instruments, Palo Alto, California) using an SW39 rotor. Fractions of uniform size (five drops; approximately $0.2 \mathrm{ml}$ ) were collected from centrifuged gradients at a constant rate by upward displacement with an automatic fractionator (ISCO Model 182, Instrumentation Specialties Co., Lincoln, Nebraska). Agglutinating activity was detected in fractionated samples following the addition of $0.2 \mathrm{ml}$ whole cells (serum and mucus from immunized animals) or boiled cells (mucus extracts from infected animals) to serial doubling dilutions. The test was read as positive if 75 to $100 \%$ clearing occurred following incubation in a waterbath at $48^{\circ} \mathrm{C}$ for $24 \mathrm{hr}$. Duplicate fractions were subjected to agar gel diffusion (Munoz, 1971) with sera monospecific for bovine immunoglobulins IgA, IgG and IgM.

\section{RESULTS}

In nine actively immunized animals, maximum serum titres (titres throughout will be expressed as reciprocals) ranged between 3200 and 51,200 with whole cells, and between 800 and 1600 with boiled cells. Mean serum titres with each antigen were 6923 (S.D. \pm 1548 ) and 442 (S.D. \pm 537 ), respectively. Maximum titres occurred between 5 and 8 weeks after the first immunization. Vaginal mucus agglutinins toward whole cells were detected in one heifer within the 1st week after immunization; all had developed at least one positive sample by the 6 th week. Of 111 samples of vaginal mucus extract tested, fiftyfour produced positive reactions with whole cells, the maximum titres in extracts from individual animals ranging from 25 to 3200 . The mean titre was 525 (S.D. \pm 1858 ). No animal produced fewer than two positive samples during the test period which varied from 12 to 14 weeks for individual animals. When boiled cells were used, seven of ninety-five samples of vaginal mucus 


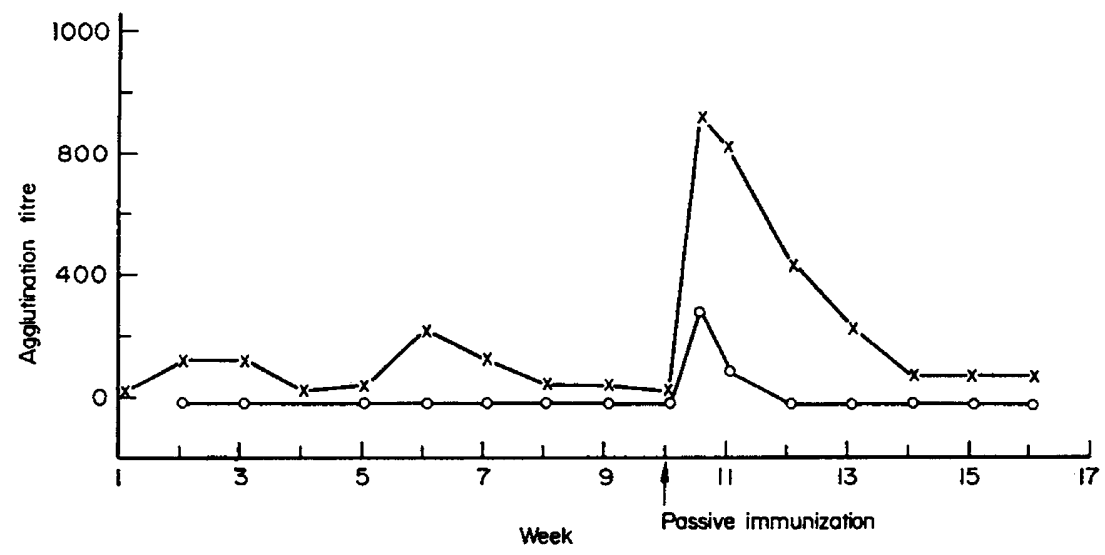

TexT-Fig. 1. Serum $(x)$ and vaginal mucus $(0)$ V. fetus whole-cell agglutinating titre following passive immunization of a heifer.

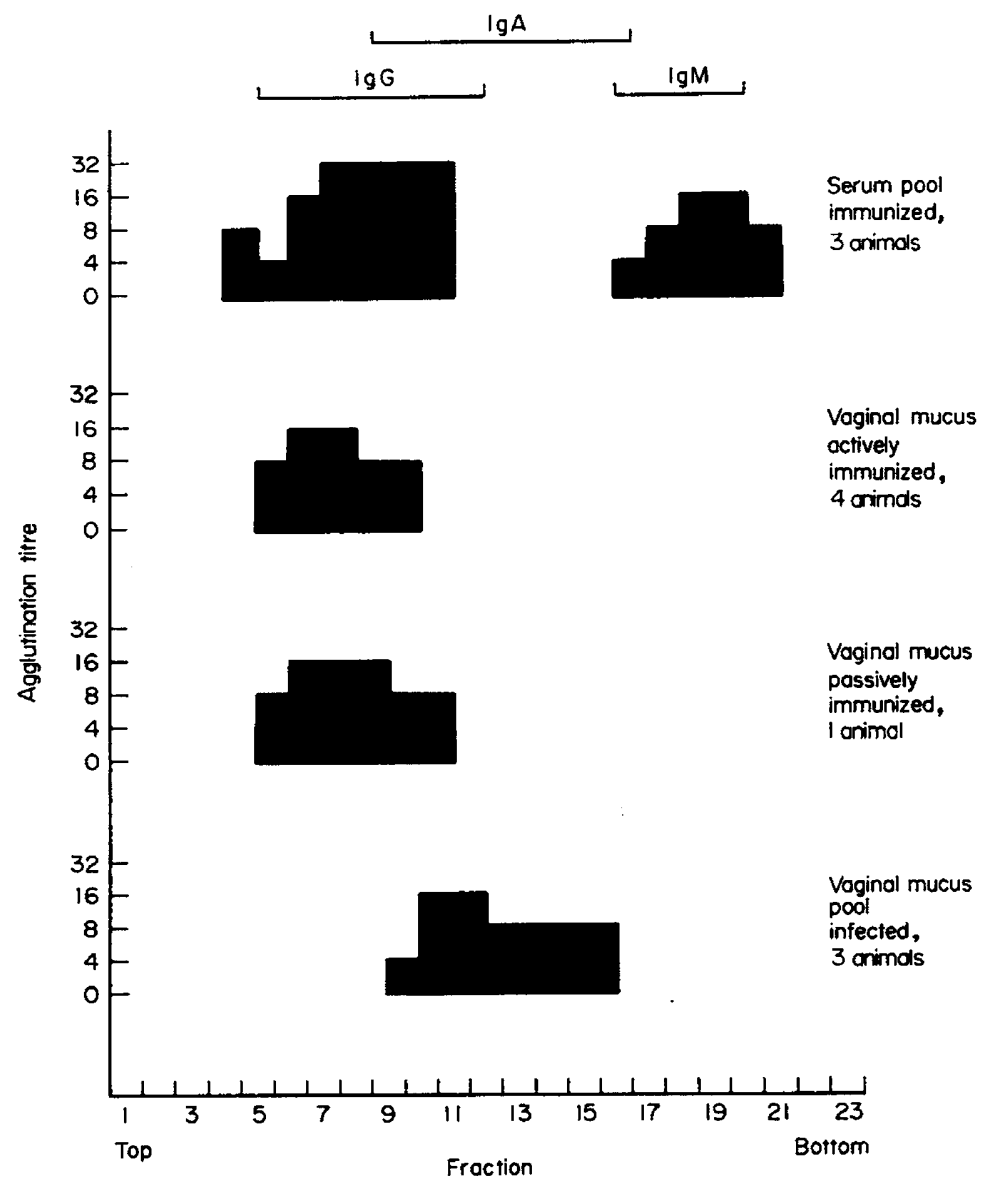

TEXT-FIG. 2. Fractionation by density gradient centrifugation of serum and vaginal mucus from heifers immunized and infected with $V$. fetus. Location of immunoglobulin classes indicated by bars. Agglutinating activity indicated by shaded areas. Serum and mucus fractions of immunized animals tested with whole cells. Fractions of vaginal mucus from infected animals tested with boiled cells. 
extract produced positive reactions, the earliest occurring 8 weeks after the initial immunization. Maximum titres ranged between 25 and 100; the mean titre was 16 (S.D. \pm 27 ). The seven positive reactions occurred in samples from five heifers. Vaginal mucus titres developed as serum titres increased but there was no 'threshold' titre in serum beyond which vaginal mucus became positive.

Saline extracts of eleven of the vaginal mucus samples collected from ten non-vaccinated heifers infected with $V$. fetus venerealis agglutinated boiled cells in dilutions of 25 to 3200 (mean 500). The single sample which agglutinated boiled cells at a titre of 3200 agglutinated whole cells at 50 ; all others failed to agglutinate whole cells.

Results of passive immunization are presented in Text-fig. 1. The pooled transfused serum agglutinated whole $V$. fetus cells at a dilution of 3200 and boiled cells at 200. A rapid rise in serum titre to whole cells was accompanied by the transient appearance of vaginal mucus whole cell agglutinins. On Days 1 and 2 after passive immunization, agglutinating activity to whole cells was also detected in nasal secretions but not in tears or saliva.

The location of immunoglobulin classes on centrifuged sucrose gradients is illustrated in Text-fig. 2, with the location of $V$. fetus agglutinating activity in correspondingly fractionated gradients of the same samples. Where a pooled sample was used to obtain these results, the number of individual samples is indicated. Serum agglutinating activity in immune animals occurred in association with $\operatorname{IgG}$ and $\operatorname{IgM}$ whereas in vaginal mucus of actively and passively immunized cattle, activity was found only in IgG-containing fractions. Vaginal mucus agglutinins occurring as a result of local infection with $V$. fetus were associated with IgA.

\section{DISCUSSION}

The data indicate that systemic immunization of cattle can result in the appearance of antibodies in the IgG class within the cervico-vaginal secretions. It is clear that the observed antibody activity is due at least in part to transudation from the high degree of correlation between IgG and albumin in vaginal mucus (Duncan, Wilkie, Hiestand \& Winter, 1972) and from passive immunization which resulted in the appearance of $V$. fetus agglutinins in secretions. The lack of detectable IgM agglutinins in vaginal mucus under these circumstances can be ascribed to the relative inefficiency of $\operatorname{IgM}$ transudation since it is restricted predominantly to the intravascular space (Waldmann, 1969), and is in low concentrations (Duncan, Wilkie, Hiestand \& Winter, 1972) which are not correlated with those of albumin (Duncan, 1971) in vaginal secretions.

In marked contrast to the IgG antibody content in vaginal mucus after systemic immunization with $V$. fetus bacterins, local infection of the reproductive tract with $V$. fetus stimulated agglutinins of the IgA class. The local synthesis of these IgA antibodies may be inferred from the known capability of the endometrium and vagina of synthesizing IgA as demonstrated by organ culture techniques (Butler, Maxwell, Pierce, Rock, Asofsky \& Kiddy, 1971; J. R. Duncan and B. N. Wilkie, unpublished observations) and the absence of altered 
$V$. fetus agglutinating titres in sera of infected heifers (Winter, 1965; Wilkie \& Winter, 1971b). The possibility that IgA O-antibodies were transferred from serum is also minimal because, although $V$. fetus $\mathrm{O}$-antibodies occur in serum both in normal and infected heifers (Winter, 1965), the proportion of these which belong to the IgA class is very small (Duncan, Wilkie \& Winter, 1972) and the overall serum content of IgA in cattle is exceedingly low (Vaerman, 1970; Mach \& Pahud, 1971; Butler, 1971; Duncan, Wilkie, Hiestand \& Winter, 1972). The virtual lack of IgG and IgM agglutinins against $V$. fetus in mucus extracts from infected heifers is puzzling because all three classes of immunoglobulins are synthesized in the bovine genital tract in vitro (Butler et al., 1971) and $V$. fetus antibodies in each of the three classes have been detected in cervico-vaginal secretions with the indirect fluorescent antibody (IFA) reaction (Pederson, Aalund, Nansen \& Adler, 1971). The IFA test is more sensitive than the agglutination test (Duncan, Wilkie \& Winter, 1972) and does not discriminate in the detection of antibodies belonging to different classes. It is thus possible that low levels of IgG antibodies, being inefficient agglutinins, would not have been detected; the absence of agglutinating activity in the IgM class indicates either that IgM antibodies were present in extremely low quantities or that blocking antibodies occurred in concentrations sufficient to inhibit the reactions.

The predominant whole-cell specificity of vaginal mucus agglutinins following vaccination was probably the consequence of the relatively higher serum whole-cell titre (cf. boiled-cell titre), providing a higher concentration of immunoglobulin of this specificity for transfer to vaginal mucus. The reason for the predominant specificity of IgA antibody in vaginal mucus toward the $\mathrm{O}$ determinant is not clear. It appears to be a feature common to the immune response at any mucous membrane following local antigenic stimulation with $V$. fetus (Duncan, Wilkie \& Winter, 1972), possibly related to loss of superficial somatic antigens before contact with immunocompetent cells in subepithelial areas (Wilkie \& Winter, 1971a).

\section{REFERENCES}

ADLER, H. C. (1959) Genital vibriosis in the bovine. An experimental study on the influence of early embryonic mortality. Acta vet. scand. 1, 1.

Avrameas, S. \& Ternynck, T. (1969) The cross-linking of proteins with gluteraldehyde and its use for the preparation of immunoadsorbents. Immunochemistry, 6, 53.

Binaghi, R. A., Oriol, R. \& Boussac-Aron, Y. (1967) Immunogenicity of heterologous Fc and Fab immunoglobulin fragments in rabbits, guinea-pigs and rats. Immunology, 13, 63.

BoYD, H. (1955) Bovine genital vibriosis, a large scale field investigation using the vaginal mucus agglutination test. Almquist and Wiksells Boktryckeri AB, Uppsala.

Butler, J. E. (1971) Symposium. The bovine immune system. F. Diary Sci. 54, 1309.

Butler, J., Maxwell, G. G., Pierce, G. S., Rock, C. A., Asofsky, R. \& Kiddy, G. S. (1971) The distribution and studies on the synthesis of bovine IgA. Proc. Soc. exp. Biol. Med. (in press).

Clark, B. L., Dufty, J. H. \& Monsbough, M. J. (1968) Experimental Vibrio fetus (venerealis infection in heifers. The immunizing properties of killed organisms injected subcutaneously.) Aust. vet. 7. 44, 110.

Glark, B. L., Dupty, J. H. \& Monsbough, M. J. (1970) Vaccination of heifers with Vibrio fetus (intestinal type) against infection with Vibrio fetus (genital type). J. comp. Path. 80, 47.

Glark, B. L., Newsam, I. D. B., Monsbough, M. J. \& Dufty, J. H. (1967) Experimental Vibrio fetus infection in cows. Studies on the immunizing properties of living organisms injected subcutaneously. Aust. vet. 7. 43, 341. 
Duncan, J. R. (1971) Serum and secretory immunoglobulins of cattle: characterization, quantitation, and distribution of antibody activity for Vibrio fetus. Thesis, Gornell University, Ithaca, New York.

Duncan, J. R., Wilkie, B. N., Hiestand, F. \& Winter, A. J. (1972) The serum and secretory immunoglobulins of cattle: characterization and quantitation. F. Immun. 108, 965.

Duncan, J. R., Wilkie, B. N. \& Winter, A. J. (1972) Natural and immune antibodies for Vibrio fetus in serum and secretions of cattle. Infect. \& Immunity, 5, 728.

Florent, A. (1960) Les deux vibrioses genitales: la vibriose due à Vibrio fetus venerealis et la vibriose d'origine intestinale due à Vibrio fetus intestinalis. Ucele, Institut National de Recherches Veterinaries. Ghent, Riiksuniversitut Vecart Senijschool Mededligem.

Frank, A. H., Bryner, J. H. \& O'BerRy, P. A. (1964) Reproductive patterns of female cattle bred for successive gestations to Vibrio fetus-infected bulls. Am. J. vet. Res. 25, 988.

Hoerletn, A. B. \& Carroll, E. J. (1970) Duration of immunity to bovine genital vibriosis. F. Am. vet. med. Ass. 156, 775.

Hughes, D. E. (1953) A study of the diagnosis of bovine vibriosis with special reference to the detection of agglutinins in the vaginal secretions. Cornell Vet. 43, 431.

Kramer, T. \& Hoerlein, A. B. (1969) Serologic response of heifers vaccinated and exposed to vibriosis. Am. F. vet. Res. 30, 1089.

Larsen, K. \& Ringer, L. (1967) Serologic analysis of bovine vibriosis. Am. 7. vet. Res. 28, 1231.

Lawson, J. R. \& McKinnon, P. J. (1952) Vibrio fetus infection in cattle. Vet. Rec. 64, 768.

MACH, J. P. \& PaHUd, J. J. (1971) Secretory IgA, a major immunoglobulin in most bovine external secretions. F. Immun. 106, 552.

Munoz, J. (1971) Double diffusion in plates. In: Methods in Immunology and Immunochemistry, Vol. III, p. 152. Eds. C. A. Williams and M. W. Chase. Academic Press, New York and London.

Pederson, K. B., Aalund, O., Nansen, P. \& Adler, H. G. (1971) Immunofluorescent immunoglobulin differentiation of Vibrio fetus antibodies from bovine cervico-vaginal secretions. Acta vet. scand. 12, 303.

Ristic, M., White, F. H., Doty, R. B., Herzberg, H. \& Sanders, D. A. (1957) The characteristics of agglutinating antigens of Vibrio fetus variants. I. Effects of heat and formalin on serological activity. Am. 7. vet. Res. 18, 764 .

Stegenga, T. \& Terpstra, J. I. (1949) Over Vibrio fetus infecties bij het rund en 'enzootisch' steriliteit. Tijschr. Diergeneesk. 74, 293.

SzABo, L. (1951) Improved sampling method for demonstration of local antibodies in the vagina. Nature, Lond. 166, 171.

Terpstra, J. J. \& Eisma, W. A. (1951) Vibrio fetus infection in cattle and enzootic infertility. Tijdschr. Diergeneesk. 76, 433.

VAERMAN, J. P. (1970) Studies on IgA immunoglobulins in man and animals. Thesis, Université Gatholique de Louvain, Louvain, Belgium.

Vandeplassche, M. A., Florent, R., Bouters, R., Huysman, A., Brone, E. \& DeKeyser, P. (1963) The pathogenesis, epidemiology and treatment of Vibrio fetus infection in cattle. C. r. Rech. Inst. Encour. Rech. scient. Ind. Agric. 29, 1.

Waldman, T. A. (1969) Disorders of immunoglobulin metabolism. New Engl. F. Med. 281, 1170.

Wridik, R. W. \& Hlidar, G. E. (1955) Untersuchungen über die antigene Struktur von Vibrio fetus vom Rind. Das Kapsel oder K-Antigene von Vibrio fetus. Zentbl. VetMed. 2, 238.

WILKIE, B. N. \& WINTER, A. J. (1971a) Location of Vibrio fetus var. venerealis within the endometrium of the cow. Infect. \& Immunity, 3, 854.

WiLKIE, B. N. \& Winter, A. J. (1971b) Bovine vibriosis: the distribution and specificity of antibodies induced by vaccination and infection and the immunofluorescent localization of the organism in infected heifers. Can. J. comp. Med., 35, 301.

WINTER, A. J. (1965) Characterization of the antibody for Vibrio fetus endotoxin in sera of normal and V. fetus infected cattle. F. Immun. 95, 1002. 